Мальцев Д.В.

ДІАГНОСТИКА І ЛІКУВАННЯ ПЕРВИННИХ МІНОРНИХ ІМУНОДЕФІЦИТІВ У ПАЦІЕНТІВ З РЕЦИДИВНИМИ УРОГЕНІТАЛЬНИМИ ІНФЕКЦІЯМИ ТА ІМУНОЗАЛЕЖНИМ БЕЗПЛІДДЯМ

НДІ ЕКМ Начіонального медичного університету імені О.О. Богомольия

\title{
Maltsev D.
}

\section{DIAGNOSIS AND TREATMENT OF PRIMARY MINOR IMMUNODEFICIENCIES IN PATIENTS WITH RECURRENT UROGENITAL INFECTIONS AND IMMUNE-DEPENDENT INFERTILITY}

\author{
ECM Research Institute of the O. Bogomolets National Medical University
}

Резюме. Наразі з'ясовано, що у пацієнтів з невпинно рецидивними урогенітальними інфекціями, викликаними умовно патогенною та опортуністичною мікрофлорою, відзначається стан імуносупресії. Сукупний аналіз відомих частот поширеності 30 відомих нині малих імунних дисфункцій людини дозволяє дійти висновку, що наразі принаймні 20\% представників сучасної популячії (тобто кожна п'ята людина) уражені хоча б одним первинним мінорним імунодефічитом. Це протирічить усталеним, однак помилковим поглядам щодо раритетності первинних імунодефіцитів у людей. Тому діагностика первинних мінорних імунодефіцитів має бути невід'ємним компонентом сучасної рутинної медичної практики спеціалістів різного профілю. В даній статті наведена класифікація мінорних первинних імунодефіцитів людини, розглянуті відмінності між великими і малими імунними дисфункціями, а такожрозглянуто алгоритм клінічної діагностики первинних мінорних імунодефріцитів та сучасні підходи до їх лікування. Виявлення генетично детермінованої хвороби імунної системи не тільки може пояснити атиповий перебіг умовно патогенних або опортуністичних інфекцій урогенітального тракту і зниження фертильності, однак й може відкрити шлях до призначення адресної імунотерапії, спрямованої на компенсацію причинового імунодефіииту. Це може вивести ефективність застосовуваних терапевтичних втручань на якісно новий рівень, розв'язавши навіть важкі клінічні проблеми.

Ключові слова: імунотерапія, імунопрофілактика, імунодіагностика, в/в імуноглобулін, читокінотерапія, трансплантація кісткового мозку.

Наразі з'ясовано, що у пацієнтів 3 невпинно рецидивними урогенітальними інфекціями, викликаними умовно патогенною та опортуністичною мікрофлорою, відзначається стан імуносупресії [8]. Цей стан може бути зумовлений первинним або вторинним імунодефіцитом. У разі відсутності очевидних причин вторинного імунодефіциту, наприклад, СНІДу, прийому імуносупресивних ліків або важкої вади серця [48], слід здійснювати пошук первинної хвороби імунної системи. Наразі у людей описано більше 300 первинних імунодефіцитів, більшість з яких рідко зустрічається і призводить до розвитку важких, драматичних клінічних симптомів, нерідко асоційованих з смертельним наслідком в ранньому дитячому віці. Проте відомо близько 30 первинних мінорних 
імунодефіцитів, що часто зустрічаються в популяції і проявляються у вигляді м'якших клінічних симптомів [8]. В рутинній практиці уролога, андролога та репродуктолога важливою $\epsilon$ діагностика мінорних первинних імунодефіцитів у пацієнтів з важкокурабельними часто рецидивними урогенітальними інфекціями та пов'язаними з ними імунозалежними формами безпліддя, включаючи випадки антигаметного автоімунітету. Виявлення генетично детермінованої хвороби імунної системи не тільки може пояснити атиповий перебіг умовно патогенних або опортуністичних інфекцій урогенітального тракту і зниження фертильності, однак й може відкрити шлях до призначення адрес- ної імунотерапії, спрямованої на компенсацію причинового імунодефіциту. Це може вивести ефективність застосовуваних терапевтичних втручань на якісно новий рівень, розв'язавши навіть важкі клінічні проблеми.

Якщо імунодефіцит принаймні в 20\% випадків має асимптомний перебіг, вважають за доцільне оцінювати його як малу імунну дисфункцію, або мінорний імунодефіцит [8]. Натомість класичні, або великі імунодефіцити майже завжди проявляються у вигляді типового синдромокомплексу імунозалежних уражень, які нерідко поєднуються з додатковими симптомами, як наприклад при синдромі Віскотта-Олдрича [55] (рис. 1).

\section{Імунодефіцитні хвороби людини}

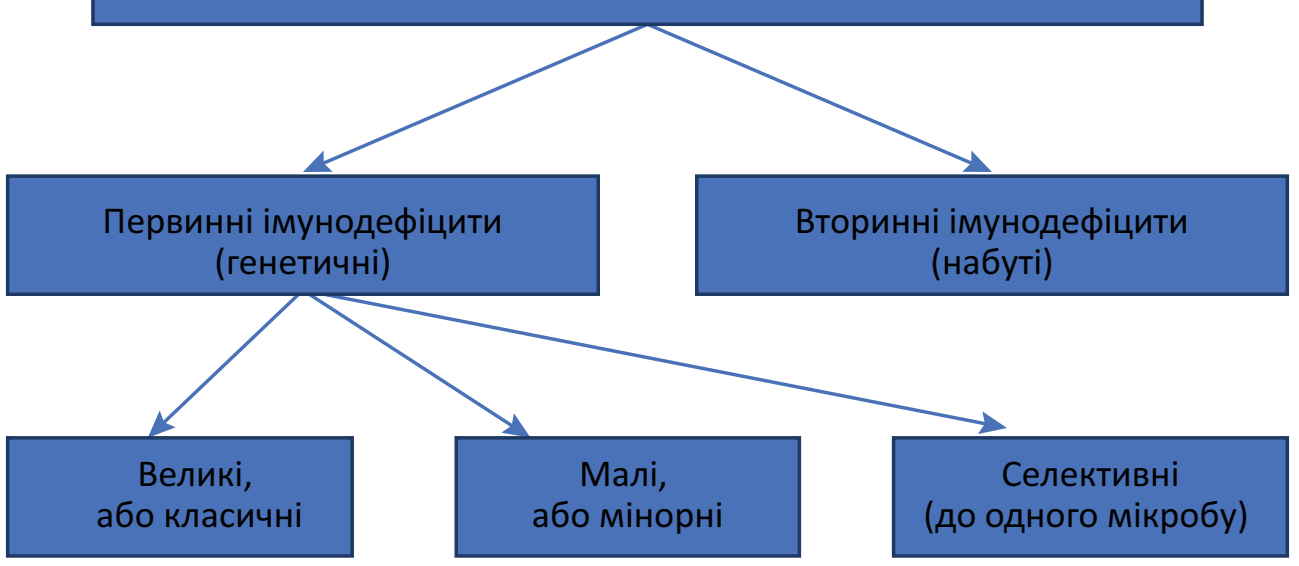

Puc. 1. Класифікація імунодефіцитних хвороб людини

Розподіл на малі (мінорні) і великі (класичні) імунодефіцити важливий, однак досить умовний. Відомі випадки легких форм класичних імунодефіцитних хвороб, при яких відзначається малосимптомний перебіг імунодефіциту, тоді як при малих імунних дисфункціях описані важкі, фульмінантні клінічні прояви, що призводили до смерті пацієнта [40]. Хоча між малими і великими імунодефіцитами більше спільного, ніж відмінного, все ж таки виділення окремої групи мінорних імунних дисфункцій важливе з огляду на принципові особливості таких хво- роб, незнання або нерозуміння яких може перешкоджати їх активному виявленню i лікуванню. Згідно з класичними поглядами постулюється, що первинні імунодефіцити - рідкісні хвороби, які проявляються 3 народження або, принаймні, 3 раннього дитячого віку, супроводжуються важкими, потенційно летальними інфекціями і зумовлюють смерть пацієнта у разі відсутності адекватних терапевтичних втручань, здебільшого - пересадки кісткового мозку або генної терапії [59]. Тим не менше, малі імунодефіцити часто зустрічаються у популяції, 
причому такими хворобами наразі уражено щонайменше $20 \%$ представників популяції, можуть мати асимптомний перебіг протягом певних періодів онтогенезу, дебютувати клінічно в будь-якому віці, навіть у похилих пацієнтів, характеризуються гетерогенністю проявів, варіабельністю клінічного перебігу і непередбачуваністю прогнозу [47] (табл. 1). Такі імунодефіцити у багатьох пацієнтів не викликають інфекційних проявів, а маніфе- стують лише у вигляді алергії, автоімунітету або синдрому пухлинного росту. Більшість пацієнтів $з$ малими імунодефіцитами не потребують проведення потенційно небезпечних радикальних терапевтичних втручань і можуть бути принаймні частково компенсовані за рахунок імуномодулюючої або замісної імунотерапії, необхідність в яких здебільшого епізодична, а не пожиттєва [30].

Табл. 1

Порівняльна характеристика великих і мінорних імунодефіцитів

\begin{tabular}{|c|c|c|}
\hline Ознака & Великий імунодефіцит & Мінорний імунодефіцит \\
\hline Кількість відомих хвороб & Більше 300 & Близько 30 \\
\hline $\begin{array}{l}\text { Кількість уражених чин- } \\
\text { ників імунної системи }\end{array}$ & Зазвичай декілька чинників & Зазвичай один чинник \\
\hline Важкість симптомів & $\begin{array}{l}\text { Важкий, загрозливий життю } \\
\text { клінічний фенотип }\end{array}$ & $\begin{array}{l}\text { Варіабельний фенотип з широ- } \\
\text { ким діапазоном проявів }\end{array}$ \\
\hline Клінічний перебіг & $\begin{array}{l}\text { Прогресуючий з тенденцією } \\
\text { до ранньої летальності }\end{array}$ & $\begin{array}{l}\text { Варіабельний з періодами заго- } \\
\text { стрень і ремісій }\end{array}$ \\
\hline Частота в популяції & Менше 1\% & Близько 20\% \\
\hline $\begin{array}{l}\text { Можливість асимптомно- } \\
\text { го перебігу }\end{array}$ & В раритетних випадках & Щонайменше в 20\% випадків \\
\hline Дебют симптомів & У ранньому дитячому віці & В будь-який період онтогенезу \\
\hline $\begin{array}{l}\text { Типовість клінічних симп- } \\
\text { томів }\end{array}$ & Є типовий фенотип & $\begin{array}{l}\text { Гетерогенна клінічна картина, яка } \\
\text { відрізняється навіть у найближ- } \\
\text { чих родичів }\end{array}$ \\
\hline Прогноз & $\begin{array}{l}\text { Несприятливий без специфіч- } \\
\text { ного лікування }\end{array}$ & $\begin{array}{l}\text { Зазвичай сприятливий, однак } \\
\text { може бути непередбачуваним }\end{array}$ \\
\hline
\end{tabular}

Наразі відомо близько 30 форм первинних мінорних імунодефіцитів людини, які мають бути самостійними клінічними нозологіями. Відповідно до цього, розроблена спеціальна класифікація цих імунних дисфункцій для клінічної практики [8]. Розподіл хвороб в цій класифікації ґрунтується на ураженій ланці імунітету. Так, виділені первинні мінорні імунодефіцити з вибірковим залученням клітинної і гуморальної ланок імунітету, а також - компонентів природженого і адаптивного (набутого) імунітету організму людини. В кожній з цих підгруп можуть бути виділені кількісні та якісні порушення.

\section{I. Порушення клітинної ланки природ- женого імунітету:}

А. Кількісні:

а) порушення з боку нейтрофілів:

- сімейна доброякісна нейтропенія $[13,23]$;

- хронічна ідіопатична нейтропенія [29];

- циклічна нейтропенія [64]

б) порушення з боку лімфоцитів:

- дефіцит природних кілерів [17];

- дефіцит природних кілерних Т-лімфоцитів [3];

- дефіцит молекули CD16 [24] 
Б. Якісні:

- дефіцит мієлопероксидази фагоцитів [47];

- дефіцит еозинофільної пероксидази [46];

- дефіцит молекули CD64 [61]

\section{II. Порушення гуморальної ланки природ-} женого імунітету:

- дефіцит білків системи комплементу, насамперед, дефіцит С2 і термінальних компонентів С6-С9 [52];

- дефіцит маннозозв'язуючого протеїну (лектину) [63];

- дефіцит серинової протеази 2 типу, асоційованої з маннозозв'язуючим протеїном [58];

III. Дефіцит клітинної ланки адаптивного імунітету:

- ідіопатична CD4+ Т-клітинна лімфопенія [15, 53];

- дефіцит молекули CD8 [25]

IV. Дефіцит гуморальної ланки адаптивного імунітету:

- транзиторна гіпоімуноглобулінемія немовлят [39];

- некласифікована гіпоімуноглобулінемія [41];
- дефіцит lgM [37];

- дефіцит субкласів IgG [42];

- дефіцит IgA [54];

- дефіцит секреторного IgA [5];

- дефіцит IgE [18];

- дефіцит IgD [43];

- дефіцит специфічних антитіл [62];

- інші дисімуноглобулінемії (поєднані і комбіновані дефіцити імуноглобулінів) $[4,8]$

В табл. 2 продемонстровані дані щодо поширеності різних форм мінорних імунодефіцитів в сучасній людській популяції. Найбільшу поширеність 3-поміж відомих наразі первинних мінорних імунодефіцитів людини має вибірковий дефіцит lgD, який відзначається серед 6-9\% представників сучасної популяції [43], та дефіцит маннозозв'язуючого лектину, який зустрічається серед 5-10\% мешканців Землі $[1,63]$. Найменша поширеність притаманна дефіциту компоненту комплементу C2 та дефіциту мієлопероксидази фагоцитів, котрі реєструються частотою 1 випадок на 2000 мешканців $[2,52]$.

Табл. 2

Поширеність малих імунодефіцитних хвороб серед сучасних людей

\begin{tabular}{|l|c|}
\hline \multicolumn{1}{|c|}{ Імунодефіцитна хвороба } & Частота \\
\hline Дефіцит IgM & $1: 385$ в $€_{\text {вропі [37] }}$ \\
\hline Дефіцит IgG1 & $1: 26$ в Європі [42] \\
\hline Дефіцит IgG4 & $1: 400$ в Європі [33] \\
\hline Дефіцит IgA & $1: 160-1: 500$ в Європі і CША [45], \\
& $1: 2000-1: 4000$ в Китаї [27] \\
\hline Дефіцит IgE & $1: 30$ в Європі [26] \\
\hline Дефіцит IgD & $1: 12-1: 14$ в Європі [31] \\
\hline Дефіцит маннозозв'язуючого протеїну & $1: 10-1: 20$ в Європі [63] \\
\hline Дефіцит компоненту комплементу С2 & $1: 10000$ (гомозиготи), \\
& $1: 50-1: 100$ в Європі (гетерозиготи) [52] \\
\hline Дефіцит компоненту комплементу С9 & $1: 1000$ в Японії [36] \\
\hline Дефіцит мієлопероксидази фагоцитів & $1: 2000-1: 4000$ в Європі і США [47], \\
& $1: 10000$ в Японії [49] \\
\hline Ідіопатична СD4+ Т-клітинна лімфопенія & $1: 400$ в Європі [22] \\
\hline
\end{tabular}


Сукупний аналіз відомих частот поширеності 30 відомих нині малих імунних дисфункцій людини дозволяє дійти висновку, що наразі принаймні 20\% представників сучасної популяції (тобто кожна п'ята людина) уражені хоча 6 одним первинним мінорним імунодефіцитом. Сукупна питома вага більше 300 відомих нині великих імунодефіцитів складає менше $1 \%$ сучасних людей, що підтримує тезу щодо рідкісності такої патології. Таким чином, хоча кількість форм первинних мінорних імунодефіцитів більше, ніж в 10 разів, нижча порівняно $з$ класични- ми хворобами імунної системи, малі імунні дисфункції на даний момент уразили щонайменше в 20 разів більшу кількість сучасних людей, будучи досить поширеною патологією, яка серйозно впливає на популяційне здоров'я (рис. 2). Це протирічить усталеним, однак помилковим поглядам щодо раритетності первинних імунодефіцитів у людей. Тому діагностика первинних мінорних імунодефіцитів має бути невід'ємним компонентом сучасної рутинної медичної практики спеціалістів різного профілю.

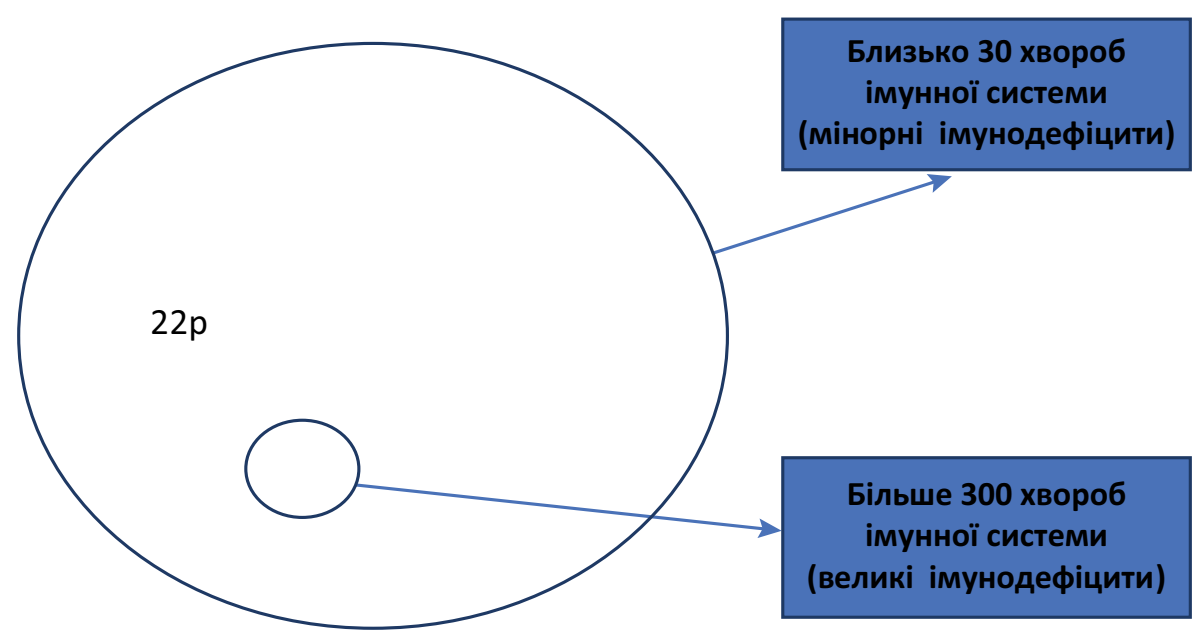

Puc. 2 Порівняння питомої ваги великих і мінорних імунодефріцитів в сучасній людській популячії

При діагностиці мінорних первинних імунодефіцитів у часто і тривало хворіючих урологічних пацієнтів та осіб з імунозалежними формами безпліддя важливим $\epsilon$ правильне компонування імунограм, які мали 6 включати визначення всіх показників, пов'язаних з ідентифікацією поширених в популяції хвороб імунної системи. Наразі немає жодного лабораторного центру в Україні, імунологічні дослідження якого відповідають сучасним вимогам діагностики первинних мінорних імунодефіцитів, тому для правильної оцінки імунного статусу в таких випадках слід роботи тести в різних лабораторіях і об'єднувати їх результати при ос- таточному аналізі отриманих даних. Нижче наведено перелік тестів, які мали б входити в так звану ідеальну імунограму щодо діагностики малих імунних дисфункцій людини, яка могла 6 надати вичерпну інформацію в таких випадках.

- ЗАК з формулою

- Сироваткові концентрації імуноглобулінів різних класів ( $\lg M, \lg G, \lg A, \lg E, \lg D)$

- Сироваткові концентрації субкласів IgG (lgG1, $\lg G 2, \lg G 3, \lg G 4)$

- Концентрація секреторного IgA в слині

- Вимірювання титру специфічних антитіл до збудника інфекції в крові

- Кількість CD3+CD4+ Т-лімфоцитів 
- Кількість CD3+CD8+ Т-лімфоцитів

- Кількість CD3+CD16+CD56+ лімфоцитів

- Кількість CD3-CD16+CD56+ лімфоцитів

- Кількість CD3- CD19+ В-лімфоцитів

- Кількість CD64+ клітин в крові

- Концентрація білків системи комплементу в сироватці крові (С1-С9)

- Концентрація маннозозв'язуючого лектину в сироватці крові

- Сироваткові концентрації серинових протеаз 1 і 2, асоційованих 3 маннозозв'язуючим лектином

- Активність мієлопероксидази фагоцитів

- Активність еозинофільної пероксидази

Раціональна діагностика малої імунодефіцитної хвороби включає кілька принципових етапів, які мають реалізовуватися послідовно під час здійснення діагностичного пошуку:

A

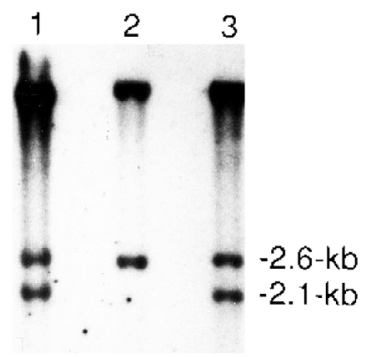

1. Фізикальне обстеження пацієнта для оцінки поточного стану його здоров'я;

2. Вивчення анамнезу з урахуванням частоти і важкості інфекційних, алергічних, імунозапальних, автоімунних і непластичних епізодів, які можуть бути пов'язані з імунодефіцитною хворобою;

3. Вивчення лабораторного фенотипу імунодефіциту, що лежить в основі імунодефіцитної хвороби;

4. Проведення диференційної діагностики і формулювання клінічного діагнозу;

5. Здійснення каріотипування i/або молекулярно-генетичного тестування для ідентифікації хромосомної аберації, мутації або поліморфізмів генів, з якими пов'язаний імунодефіцит (рис. 3).

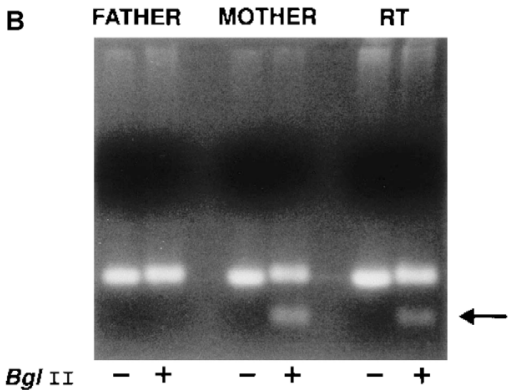

Puc. 3. Ідентифікація мутації R569W у пацієнта з дефіцитом мієлопероксидази фагоцитів (за Nauseef W.M. зі спів.) [47]

Перебіг малих імунодефіцитних хвороб непередбачуваний. Безсимптомність протягом попереднього періоду онтогенезу не гарантує гладкого перебігу імунодефіциту в подальшому, так само як і важкі інфекційні прояви та імунозалежні ускладнення не вказують на неможливість спонтанної або медикаментозно-індукованої ремісії хвороби. Сприятливий перебіг імунодефіциту у родичів не може бути екстрапольований на пробанда у зв'язку з безпрецедентною варіабельністю перебігу навіть у членів однієї родини. Відомі випадки, коли один фатальний епізод інфекції у зрілому віці був єдиними проявом малої імунодефіцитної хвороби [40]. Загалом, кількісні форми імуноде- фіциту прогностично несприятливіші за якісні, а комбіновані порушення мають найгірший прогноз. Імунодефіцити 3 широким діапазоном флуктуації рівня імунологічного показника зазвичай мають легший перебіг за імунні дисфункції зі стійким глибоким дефіцитом певного імунного чинника. У дітей гуморальні імунодефіцити принаймні в половині випадків зазнають спонтанної компенсації до пубертатного віку. Клітинні малі імунодефіцити характеризуються гіршим прогнозом за гуморальні і фагоцитарні, оскільки в їх картині переважають важкі вірусні інфекції та неоплазії. Рівні CD4+ Т-лімфоцитів <150 клітин/мл і природних кілерів - <100 клітин/мл крові $\epsilon$ предикторами ле- 
тального результату при ідіопатичній Т-клітинній лімфопенії, як зазначають Régent A. зі спів. [53]. Незважаючи на наявність малосимптомних форм, загалом малі імунодефіцитні хвороби асоційовані зі скороченням терміну життя людини. Так, в нещодавньому популяційному когортному дослідженні за участю 2495 пацієнтів з тотальним дефіцитом IgA і 24509 осіб загальної популяції показаний підвищений ризик смерті пацієнта протягом перших 10-15 років після постановки діагнозу даної імунодефіцитної хвороби [45].

Модифікація способу життя та симптоматичне лікування супутніх проявів, таких як тривога, депресія або інсомнія, можуть суттєво покращити якість життя пацієнтів 3 малими імунодефіцитними хворобами, як показали Jörgensen G.H. зі спів. у контрольованому дослідженні на прикладі ізольованого дефіциту IgA у людей [38]. Профілактична або епізодична антибіотикотерапія застосовується для попередження або лікування епізодів бактеріальних інфекцій в імуноскомпрометованих пацієнтів. При розвитку вірусних і грибкових інфекцій призначаються антивірусні препарати та антимікотики згідно з профілем чутливості виявлених мікроорганізмів. Як видається очевидним, стратегія антимікробної хіміотерапії не впливає належним чином на ризик розвитку алергічних, автоімунних та непластичних ускладнень. Повторна вакцинація 23-валентною кон'югованою антипневмококовою вакциною та некон'югованою вакциною проти гемофільної палички застосовується при ізольованому дефіциті специфічних антиполісахаридних антитіл [62]. Препарат OM-85 BV (бронхо-ваксом) пройшов кілька контрольованих випробувань як засіб зменшення частоти інфекційних епізодів у пацієнтів із ізольованими дефіцитами $\lg \mathrm{A}$ i субкласів lgG [34].

Пацієнтам $з$ важкими формами імунодефіцитів, у яких не вдається знизити частоту інфекційних епізодів за допомогою стратегії антимікробного лікування, доцільно застосовувати базисну імунотерапію згідно $з$ результатами клінічних повідомлень і контрольованих випробувань. Перевагою імунотерапії $\epsilon$ не тільки системний вплив на інфекційний процес, однак і здатність допомагати при алергічних, автоімунних та неопластичних ускладненнях імунодефіциту.

При гуморальних імунодефіцитах у якості базисної імунотерапії застосовуються препарати нормального в/в імуноглобуліну людини. Під час фази насичення імуноглобулін вводять у середній дозі 600-800 мг/ кг/міс, а в фазу підтримуючої терапії - 200400 мг/кг/міс під контролем результатів вимірювання сироваткових концентрацій імуноглобулінів [6, 50, 57] (рис. 4, 5).

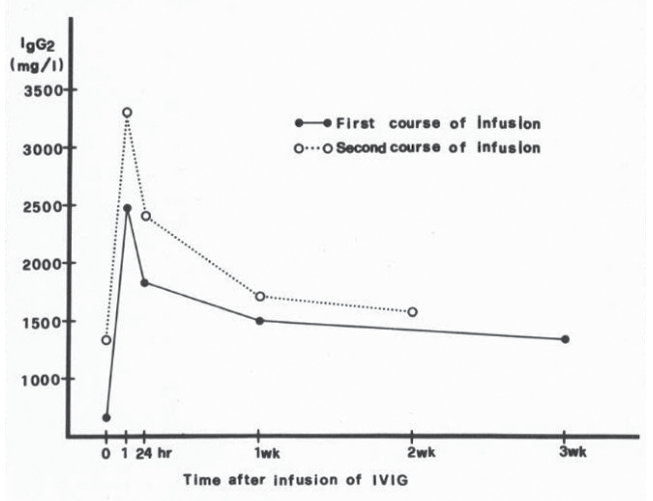

Puc. 4. Зростання сироваткової концентрачії IgG2 у пацієнта з дефіцитом цього субкласу Ig після першої (суцільна лінія) і другої (пунктир) інфузії в/в імуноглобуліну (за Chou C.C. зі спів.) [4]

У разі непереносимості в/в імуноглобуліну як виключення з правил можна застосовувати препарати 10\% в/м імуноглобуліну в дозі 25-50 мг/кг/тиждень [57]. Препарат нормального імуноглобуліну людини, збагаченого молекулами IgA та IgM, може застосовуватися при лікуванні ізольованих дефіцитів зазначених класів імуноглобулінів, однак доказова база ефективності даного лікарського засобу обмежена повідомленнями про клінічні випадки і результатами невеликих контрольованих випробувань [7, 32]. Наразі показано, що імуноглобулінотерапія - більше, ніж просто замісне лікування при гуморальних імунодефіцитах, оскільки препарати імуноглобулінів здатні модулювати антитілогенез через вплив на Fc-рецептори В-лімфоцитів [20], а також пригнічувати алергічні [51], автоімунні [21] і навіть непластичні [28] ускладнення, пов'язані з імунною дисфункцією. 

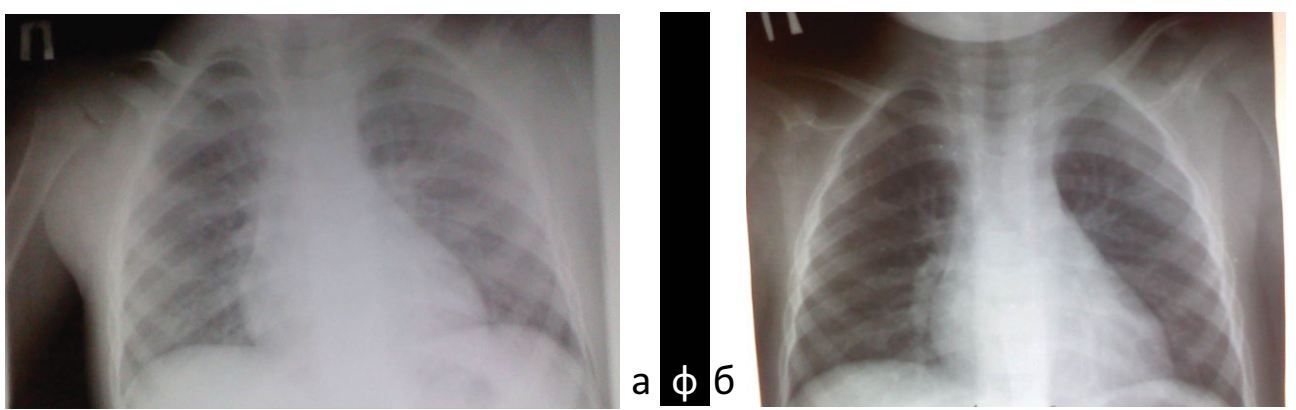

Puc. 5. Усунення проявів двобічного інтерстиційного пневмоніту EBV-етіології за даними рентгенограми органів грудної клітини у дитини з первинним тотальним дефріцитом IgE nісля проведення замісної в/в імуноглобулінотерапії (зліва - до терапії, справа - після; власне спостереження) [18]

При дефіциті маннозозв'язуючого лектину, так само як і при дефіцитах білків системи комплементу С1-С9, застосовують препарати свіжезамороженої плазми крові від сумісного донора в/в краплинно в дозі 10-15 мл/кг 1 раз на 2 тижні, оскільки у сироватці крові здорових людей містяться необхідні чинники імунітету в достатній кількості [14]. Препарати природного і рекомбінантного маннозозв'язуючого білку наразі успішно пройшли кілька контрольованих випробувань при відповідному імунодефіциті і можуть мати переваги перед плазмою крові завдяки більшій вибірковості дії та кращій переносимості [30].

При клітинних імунодефіцитах у якості базисної імунотерапії застосовують препа- рати цитокінів - природних, лімфобластоїдних і рекомбінантних інтерферонів-альфа, -бета та -гамма, а також - рекомбінантних інтерлейкінів-2 і -7 людини [9, 11, 12, 19]. Імунотерапевтичний агент тимозин-альфа1 пептидної природи успішно пройшов клінічні випробування при ідіопатичній CD4+ Т-клітинній лімфопенії [56] та ізольованому дефіциті природних кілерних Т-клітин [60] у людей. Нещодавно ми продемонстрували у контрольованому дослідженні очевидну користь від довготривалої безперервної імуномодулюючої терапії рекомбінантним інтерфероном-гамма при дефіциті мієлопероксидази фагоцитів (рис. 6) [16].

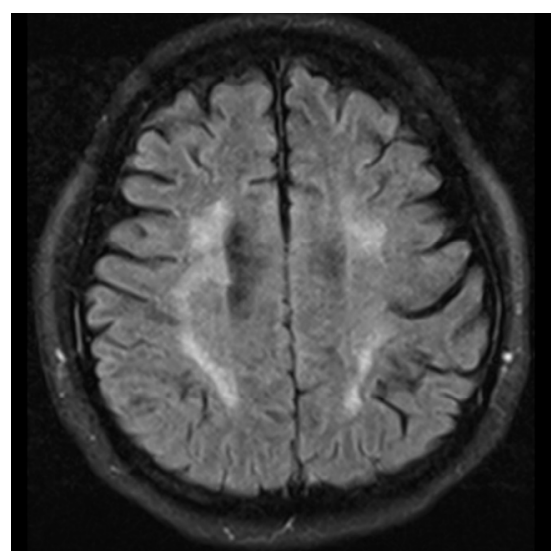

Puc. 6. Різке зменшення MP-проявів мультифокального лейкоенцефаліту HHV-6-етіологіїу пацієнта з первинним дефіцитом мієлопероксидази на тлі імунотерапії рекомбінантним гаммаінтерфероном (зліва - до терапії, справа - після; власне спостереження) [16] 
У разі первинних нейтропеній у якості базисних імунотерапевтичних агентів призначають препарати рекомбінантних гранулоцитарного і гранулоцитарно-моноцитарного колонієстимулюючих чинників у дозі 5-10 мкг/кг маси тіла п/шк, в/м або в/в краплинно від 3 разів на 1 тиждень до 2 разів на 1 місяць залежно від важкості нейтропенії під контролем результатів вимірювання абсолютного вмісту нейтрофільних гранулоцитів у периферичній крові пацієнта $[10,44]$.

Було здійснено кілька успішних спроб пересадки алогенного кісткового мозку пацієнтам 3 важкими формами ідіопатичної CD4+ Т-клітинної лімфопенії, дефіцитів природних кілерів, IgA та субкласів IgG, що забезпечувало повне відновлення імунологічного фенотипу. Tак, Suga S. зі спів. повідомили про успішну пересадку кісткового мозку 8-річному хлопчику з важким дефіцитом IgG1 від HLA-ідентичної MLC-негативної сестри, оскільки ні профілактична антибіотикотерапія, ні в/в імуноглобулін не зменшили частоту інфекційних епізодів. Після трансплантації відзначалося відновлення сироваткової концентрації lgG1 і повна компенсація клінічного статусу [59]. Однак відомі випадки неочікуваного перенесення малої імунодефіцитної хвороби реципієнту від донора, що вказує на необхідність ретельного імунологічного обстеження останнього перед трансплантацією [32].

\section{СПИСОК ЛІТЕРАТУРИ}

1. Мальцев Д.В. Дефіцит маннозозв'язувального білка // Український терапевтичний журнал. - 2015. - №1. - С. 80-89.

2. Мальцев Д.В. Дефіцит мієлопероксидази фагоцитів // Український медичний часопис. - 2014. - №4(102). - С. 94-105.

3. Мальцев Д.В. Дефіцит природних кілерних Т-клітин // Український медичний часопис. - 2015. - №1(105). - С. 65-70.

4. Мальцев Д.В. Дефіцит субкласів IgG: клініка, діагностика, лікування // Клінічна імунологія, алергологія, інфектологія. - 2015. - №5-6(84-85). - С. 8-18.

5. Мальцев Д.В. Ізольований дефіцит IgA: епідеміологія, клініка, діагностика і лікування // Клінічна імунологія, алергологія, інфектологія. - 2016. - № 1(90). - С. 5-15.

6. Мальцев Д.В. Клініка, діагностика і лікування первинного вибіркового дефіциту специфічних антитіл у людей // Журнал « Клінічна Імунологія. Алергологія. Інфектологія. - 2019. - №3 (116), - С. 5-15.

7. Мальцев Д.В. Клініка, діагностика, лікування первинного ізольованого дефіциту IgM у людей // Журнал Імунологія, алергологія, інфектологія. - 2019. - №8(121). - С. 21-26.

8. Мальцев Д.В. Малі імунодефіцитні хвороби: етіологія, патогенез, клініка, діагностика і лікування // Імунологія та алергологія. - 2018. - №3. - С. 12-24.

9. Мальцев Д.В. Показания к применению бета-интерферонов человека в клиничесой практике // Український неврологічний журнал. - 2017. - № 3. - С. 5-22.

10. Мальцев Д.В. Показания к применению колониестимулирующих факторов в клинической практике, часть $2 / /$ Клінічна Імунологія. Алергологія. Інфектологія. - 2018. - №3 (108). - С. 5-11.

11. Мальцев Д.В. Показания к применению препаратов альфа-интерферонов в клинической практике, часть 2 // Клінічна Імунологія. Алергологія. Інфектологія. - 2018. - №5(110). - С. 16-26.

12. Мальцев Д.В. Показания к применению препаратов гамма-интерферона в клинической практике. Часть1. // Клінічна імунологія, алергологія, інфектолоія. - 2017. - № 3(100). - С. 6-15.

13. Мальцев Д.В. Сімейна доброякісна нейтропенія // Клінічна імунологія, алергологія, інфектолоія. - 2017. - №1 (98). - С. 23-27.

14. Мальцев Д.В. Эффективность заместительной терапии препаратом криоконсервированной плазмы крови человека у пациентов с первичным дефицитом маннозосвязывающего лектина, страдающих хронической активной герпесвирусной инфекцией // Иммунопатология, аллергология, инфектология. - 2020. - №2. - С. 15-25.

15. Мальцев Д.В., Батушкін В.В., Мишина В.В. Ідіопатична CD4+ Т-клітинна лімфопенія: клінічна картина, діагностика і лікування // Туберкуль0з. Легеневі хвороби. ВІЛ-інфекція. - 2016. - № 2(25). - С. 99-112.

16. Мальцев Д.В., Ефективність довготривалої безперервної імуномодулюючої терапії рекомбінантним гамма- інтерфероном хворих з клінічно маніфест ними формами дефіциту мієлопероксидази нейтрофільних гранулоцитів // Врачебное дело. - 2016. - № 1-2. - С.10-15. 
17. Мальцев Д.В., Недопако Я.Я. Дефіцит природних кілерів: гетерогенність, клініка, діагностика, лікування, клінічні приклади // Український медичний часопис. - 2013. - №2(94). - С. 129-142.

18. Мальцев Д.В., Рибак І.Р., Горбенко В.Ю. Ізольований дефіцит IgЕ у людей: update // Актуальная инфектология. - 2017. - №1, T.5. - C. 8-14.

19. Alstadhaug K.B., Croughs T., Henriksen S. et al. Treatment of progressive multifocal leukoencephalopathy with interleukin 7 // JAMA. Neurol. - 2014. - Vol. 71(8). - P. 1030-1035.

20. Bayry J., Fournier E.M., Maddur M.S. et al. Intravenous immunoglobulin induces proliferation and immunoglobulin synthesis from B cells of patients with common variable immunodeficiency: a mechanism underlying the beneficial effect of IVIg in primary immunodeficiencies // J. Autoimmun. - 2011. - Vol. 36(1). - P. 9-15.

21. Bertoli L.F., Pappas D.G., Barton J.C., Barton J.C. Serum immunoglobulins in 28 adults with autoimmune sensorineural hearing loss: increased prevalence of subnormal immunoglobulin G1 and immunoglobulin G3 // BMC. Immunol. 2014. - Vol. 15. - P. 43.

22. Busch M.P., Valinsky J.E., Paglieroni T. et al. Screening of blood donors for idiopathic CD4+ T-lymphocytopenia // Transfusion. 1994. - Vol. 34(3). - P. 192-197.

23. Charles B.A., Hsieh M.M., Adeyemo A. et al. Analyses of genome wide association data, cytokines, and gene expression in African-Americans with benign ethnic neutropenia // PLoS One. - 2018. - Vol. 13(3). - e0194400.

24. de Vries E., Koene H.R., Vossen J.M. et al. Identification of an unusual Fc gamma receptor Illa (CD16) on natural killer cells in a patient with recurrent infections // Blood. - 1996. - Vol. 88(8). - P. 3022-3027.

25. De la Calle-Martin 0., Hernandez M., Ordi J., Casamitjana N. et al. Familial CD8 deficiency due to a mutation in the CD8 alpha gene // J. Clin. Invest. - 2001. - Vol. 108(1). - P. 117-123.

26. Duarte J., Deshpande P., Guiyedi V., et al. Total and functional parasite specific IgE responses in Plasmodium falciparum-infected patients exhibiting different clinical status // Malar. J. — 2007. — Vol. 4. — P. 6:1.

27. Feng L. Epidemiological study of selective IgA deficiency among 6 nationalities in China // Zhonghua. Yi. Xue. Za. Zhi. - 1992. - Vol. 72(2). P. 88-90.

28. Fishman P, Bar-Yehuda S, Shoenfeld Y. IVIg to prevent tumor metastases // Int. J. Oncol. - 2002. - Vol. 21(4). - P. 875-880.

29. Fragiadaki I., Papadakis S., Sevastaki G. et al. Increased frequency of the single nucleotide polymorphism of the DARC/ACKR1 gene associated with ethnic neutropenia in a cohort of European patients with chronic idiopathic neutropenia // Am. J. Hematol. - 2020. - Vol. 95(7). - E163-E166.

30. Frakking F.N., Brouwer N., van de Wetering M.D. et al. Safety and pharmacokinetics of plasma-derived mannose-binding lectin (MBL) substitution in children with chemotherapy-induced neutropaenia // Eur. J. Cancer. - 2009. - Vol. 45(4). - P. 505.

31. Fraser P.A., Schur P.H. Hypoimmunoglobulinemia D: frequency, family studies, and association with HLA // Clin. Immunol. Immunopathol. - 1981. - Vol. 19(1). - P. 67-74.

32. Fregonese B., Canepa C., Pasino M., Merlini M. Selective IgA deficiency. Substitute treatment with human IgA-enriched immunoglobulins // Minerva. Pediatr. - 1986. - Vol. 38(17-18). - P. 751-758.

33. Gallina R., Bottaro A., Boccazzi C. et al. The genetics of IgG4 deficiency: role of the immunoglobulin heavy chain constant region and HLA loci // Eur. J. Immunol. - 1992. - Vol. 22(1). - P. 227-233.

34. Genel F, Kutukculer N. Prospective, randomized comparison of $0 \mathrm{M}-85 \mathrm{BV}$ and a prophylactic antibiotic in children with recurrent infections and immunoglobulin A and/or G subclass deficiency // Curr. Ther. Res. Clin. Exp. - 2003. - Vol. 64(8). - P. 600-615.

35. Hammarström L., Smith C.I. Development of IgG2 deficiency in a bone-marrow-transplanted patient. Implication for generation of the anticarbohydrate antibody repertoire in subclass-deficient individuals // Transplantation. - 1987. Vol. 43(6). - P. 917-919.

36. Hayama K., Sugai N., Tanaka S. et al. High-incidence of $(9$ deficiency throughout Japan: there are no significant differences in incidence among eight areas of Japan // Int. Arch. Allergy Appl. Immunol. - 1989. - Vol. 90(4) - P. 400-404.

37. Hobbs J.R. IgM deficiency // Birth Defects Orig. Artic. Ser. - 1975. - Vol. 11(1). - P. 112-116.

38. Jörgensen G.H., Gardulf A., Sigurdsson M.I. et al. Health-related quality of life (HRQL) in immunodeficient adults with selective IgA deficiency compared with age- and gender-matched controls and identification of risk factors for poor HRQL // Qual. Life Res. - 2014. - Vol. 23(2). - P. 645-658.

39. Justiz Vaillant A.A., Wilson A.M. Transient Hypogammaglobulinemia of Infancy // 2020 In: StatPearls [Internet]. Treasure Island (FL): StatPearls Publishing; 2020.

40. Kalinski T., Jentsch-Ullrich K., Fill S. et al. Lethal candida sepsis associated with myeloperoxidase deficiency and pre-eclampsia // APMIS. - 2007. -Vol. 115(7). - P. 875-880. 
41. Karaman S., Erdem S.B., Gülez N., Genel F. The Significance of B-cell Subsets in Patients with Unclassified Hypogammaglobulinemia and Association with Intravenous Immunoglobulin Replacement Requirement // Iran. J. Immunol. - 2018. - Vol. 15(1). - P. 1-13.

42. Lacombe C., Aucouturier P., Preud'homme J.L. Selective IgG1 deficiency // Clin. Immunol. Immunopathol. - 1997. - Vol. 84(2). - P. 194-201.

43. Litwiniszyn-Krzewicka K., Kepa-Gniatkowska A., Słodek G. IgA and IgD deficiencies associated with chronic active hepatitis and systemic lupus erythematosus // Pol. Tyg. Lek. -1988. - Vol. 43(20). - P. 638-639.

44. Lubitz P.A., Dower N., Krol A.L. Cyclic neutropenia: an unusual disorder of granulopoiesis effectively treated with recombinant granulocyte colony-stimulating factor // Pediatr. Dermatol. - 2001. - Vol. 18(5). - P. 426-432.

45. Ludvigsson J.F., Neovius M., Hammarström L. IgA deficiency and mortality: a population-based cohort study // J. Clin. Immunol. - 2013. - Vol. 33(8). - P. 1317-1324.

46. Nakagawa T., Ikemoto T., Takeuchi T. et al. Eosinophilic peroxidase deficiency: Identification of a point mutation (D648N) and prediction of structural changes // Hum. Mutat. - 2001. - Vol. 17(3). - P. 235-236.

47. Nauseef W.M., Brigham S., Cogley M. Hereditary myeloperoxidase deficiency due to a missense mutation of arginine 569 to tryptophan // J. Biol. Chem. - 1994. - Vol. 269(2). - P. 1212-1216.

48. Ng L.Y., Al-Alawi K., Breatnach C. et al. Hybrid Subxiphoid Perventricular Approach as an Alternative Access in Neonates and Small Children Undergoing Complex Congenital Heart Interventions // Pediatr Cardiol. - 2020. Dec 2. Online ahead of print.

49. Nunoi H., Kohi F., Kajiwara H., Suzuki K. Prevalence of inherited myeloperoxidase deficiency in Japan // Microbiol. Immunol. 2003. - Vol. 47(7). - P. 527-531.

50. Olinder-Nielsen A.M., Granert C., Forsberg P. et al. Immunoglobulin prophylaxis in 350 adults with lgG subclass deficiency and recurrent respiratory tract infections: a long-term follow-up // Scand. J. Infect. Dis. - 2007. - Vol. 39(1). - P. 44-50.

51. Page R., Friday G., Stillwagon P. et al. Asthma and selective immunoglobulin subclass deficiency: improvement of asthma after immunoglobulin replacement therapy // J. Pediatr. - 1988. - Vol. 112(1). - P. 127-131.

52. Provost T.T., Arnett F.C., Reichlin M. Homozygous C2 deficiency, lupus erythematosus, and anti-Ro (SSA) antibodies // Arthritis Rheum. - 1983. - Vol. 26(10). - P. 1279-1282.

53. Régent A., Autran B., Carcelain G. et al. Idiopathic CD4 lymphocytopenia: clinical and immunologic characteristics and follow-up of 40 patients // Medicine (Baltimore). - 2014. - Vol. 93(2). - P. 61-72.

54. Rojas-Torres D.S., Bastidas-Yaguana D.K., Sierra-Santos L., Aguilar-Shea A.L. Importance of selective immunoglobulin A deficiency // Semergen. - 2014. - Vol. 40(3). - e65-68.

55. Román Jiménez M.G., Yamazaki Nakashimada M.A., Blancas Galicia L. Wiskott-Aldrich syndrome // Rev. Alerg. Mex. - 2010. Vol. 57(5). - P. 171-175.

56. Schulof R.S., Lloyd M.J., Cleary P.A. et al. A randomized trial to evaluate the immunorestorative properties of synthetic thymosin-alpha 1 in patients with lung cancer // J. Biol. Response Mod. - 1985. - Vol. 4(2). - P. 147-158.

57. Söderström T., Söderström R., Enskog A. Immunoglobulin subclasses and prophylactic use of immunoglobulin in immunoglobulin G subclass deficiency // Cancer. - 1991. - Vol. 68(6). - P. 1426-1429.

58. Stengaard-Pedersen K., Thiel S., Gadjeva M. et al. Inherited deficiency of mannan-binding lectin-associated serine protease 2 // N. Engl. J. Med. - 2003. - Vol. 349(6). - P. 554-560.

59. Suga S., Tanaka R., Tabata N. et al. Successful bone marrow transplantation in a child with combined lgG subclass deficiency and neutropenia // Bone Marrow Transplant. - 1995. - Vol. 16(6). - P. 847-848.

60. Sugahara S., Ichida T., Yamagiwa S. et al. Thymosin-alpha1 increases intrahepatic NKT cells and CTLs in patients with chronic hepatitis B // Hepatol Res. - 2002. - 24(4). - P. 346-354.

61. van de Winkel J.G., de Wit T.P, Ernst L.K. et al. Molecular basis for a familial defect in phagocyte expression of IgG receptor I (CD64) // J. Immunol. -1995. - Vol. 154(6). - P. 2896-2903.

62. Vendrell M., de Gracia J., Rodrigo M.J. et al. Antibody production deficiency with normal lgG levels in bronchiectasis of unknown etiology // Chest. - 2005. - Vol. 127(1). - P. 197-204.

63. Vengen I.T., Madsen H.O., Garred P. et al. Mannose-binding lectin deficiency is associated with myocardial infarction: the HUNT2 study in Norway // PLoS One. - 2012. - Vol. 7(7). - e42113.

64. Zergham A.S., Acharya U. Cyclic Neutropenia // In: StatPearls [Internet]. Treasure Island (FL): StatPearls Publishing; 2020 Jan. 2020 May 6. 


\section{PEЗЮME}

ДИАГНОСТИКА И ЛЕЧЕНИЕ ПЕРВИЧНЫХ
МИНОРНЫХ ИММУНОДЕФИЦИТОВ У
ПАЦИЕНТОВ С РЕЦИДИВИРУЮЩИМИ
УРОГЕНИТАЛЬНЫМИ ИНФЕКЦИЯМИ И
ИММУНОЗАВИСИМЫМИ БЕСПЛОДИЕМ

\author{
Мальцев Д.В. \\ НИИ ЭКМ Национального медицинского \\ университета имени А.А. Богомольча
}

На данный момент выяснено, что у пачиентов с упорно рецидивирующими урогенитальными инфекциями, вызванными условно патогенной и оппортунистической микрофлорой, отмечается состояние иммуносупрессии. Совокупный анализ известных чаcтот распространенности 30 известных ныне малых иммунных дисфункций человека позволяет сделать вывод, что по крайней мере 20\% представителей современной популячии (то есть каждый пятый человек) поражены хотя бы одним первичным минорным иммунодефицитом. Это противоречит устоявшимся, однако ошибочным взглядам относительно раритетности первичных иммунодефичитов у людей. Поэтому диагностика первичных минорных иммунодефицитов должна быть неотъемлемым компонентом современной рутинной медицинской практики специалистов различного профиля. В данной статье приведена классификачия минорных первичных иммунодефичитов человека, рассмотрены различия между большими и малыми иммунными дисфункциями, а также - рассмотрен алгоритм клинической диагностики первичных минорных иммунодефицитов и современные подходы к лечению. Выявление генетически детерминированной болезни иммунной системы не только может объяснить атипичное течение условно патогенных или оппортунистических инфекций урогенитального тракта и снижения фертильности, однако и может открыть путь к назначению адресной иммунотерапии, направленной на компенсацию причинного иммунодефицита. Это может вывести эффективность применяемых терапевтических вмешательств на качественно новый уровень, разрешив даже тяжелые клинические проблемы.
Ключевые слова: иммунотерапия, иммунопрофилактика, иммунодиагностика, в/в иммуноглобулин, цитокинотерапия, трансплантация костного мозга.

\section{SUMMARY}

\section{DIAGNOSIS AND TREATMENT OF PRIMARY MINOR IMMUNODEFICIENCIES IN PATIENTS WITH RECURRENT UROGENITAL INFECTIONS AND IMMUNE-DEPENDENT INFERTILITY}

\author{
Maltsev D. \\ ECM Research Institute of the O. Bogomolets Nation- \\ al Medical University
}

It has now been established that immunosuppressive status is observed in patients with recurrent urogenital infections caused by opportunistic and low virulent microflora. A pooled analysis of the known prevalence rates of the 30 currently known mild human immune dysfunctions suggests that at least $20 \%$ of the current population (in one in five people) is currently affected by at least one primary minor immunodeficiency. This contradicts the established but erroneous view of the rarity of primary immunodeficiencies in humans. Therefore, the diagnosis of primary minor immunodeficiencies should be an integral part of modern routine medical practice of specialists in various fields. This article presents the classification of minor primary human immunodeficiencies, considers the differences between major and minor immune dysfunctions, as well as the algorithm of clinical diagnosis of primary minor immunodeficiencies and modern approaches to treatment. Detection of genetically determined disease of the immune system can not only explain the atypical course of opportunistic or low virulent infections of the urogenital tract and reduced fertility, but can also open the way to the appointment of targeted immunotherapy to compensate for the causative immunodeficiency. This can take the effectiveness of the applied interventions to a qualitatively new level, solving even severe clinical problems.

Key words: immunotherapy, immunoprophylaxis, immunodiagnostics, intravenous immunoglobulin, cytokine therapy, bone marrow transplantation. 


\section{АВТОРСКАЯ СПРАВКА}

- Мальчев Дмитрий Валерьевич Институт экспериментальной и клинической медицины НмУ имени А.А. Богомольца, зав. лабораторией иммунологии и молекулярной биологии

- Адрес: 01601, г. Киев, просп. Победы, 34, Украина

- Тел.:

E-mail:dmaltsev@ukr.net
- Мальчев Дмитро Валерійович Інститут експериментальної і клінічної медицини Національного медичного університету імені 0.0. Богомольця, зав. лабораторією імунології і молекулярної біології

- Адреса: 01601, Київ, просп. Перемоги, 34, україна

- Тел.: (068)100-85-95

- E-mail:dmaltsev@ukr.net
- Maltsev Dmytro Experimental and Clinical Medicine Institute at the 0.0. Bogomolets National Medical University

- Address: 34 Peremohy ave., Kyiv 01601, Ukraine

- Tel.: (068) 100-85-95

- E-mail:dmaltsev@ukr.net

Стаття надійшла до редакції 03.12.2020 p. У разі виникнення питань до автора статmі, звертайтесь до редакиії журналу info@ujmh.net 